\title{
Whole-cell conversion of L-glutamic acid into gamma-aminobutyric acid by metabolically engineered Escherichia coli
}

\author{
Chongrong Ke ${ }^{1}$, Xinwei Yang ${ }^{1}$, Huanxin Rao ${ }^{1}$, Wenchao Zeng ${ }^{1}$, Meirong Hu${ }^{2}$, Yong TaO $^{2}$ and Jianzhong Huang ${ }^{1 *}$
}

\begin{abstract}
A simple and high efficient way for the synthesis of gamma-aminobutyric acid (GABA) was developed by using engineered Escherichia coli as whole-cell biocatalyst from L-glutamic acid (L-Glu). Codon optimization of Lactococcus lactis GadB showed the best performance on GABA production when middle copy-number plasmid was used as expression vector in E. coli BW25113. The highest production of GABA reached $308.96 \mathrm{~g} \mathrm{~L}^{-1}$ with 99.9 mol\% conversion within $12 \mathrm{~h}$, when E. coli $\triangle$ gabAB (pRB-lgadB) concentrated to an $\mathrm{OD}_{600}$ of 15 in $3 \mathrm{M} \mathrm{L-Glu}$ at $45^{\circ} \mathrm{C}$. Furthermore, the strain could be reused at least three cycles in $2 \mathrm{M}$ crude L-Glu with an average productivity of $40.94 \mathrm{~g} \mathrm{~L}^{-1} \mathrm{~h}^{-1}$. The total GABA yield reached $614.15 \mathrm{~g} \mathrm{~L}^{-1}$ with a molar yield over $99 \%$, which represented the highest GABA production ever reported. The whole-cell bioconversion system allowed us to achieve a promising cost-effective resource for GABA in industrial application.
\end{abstract}

Keywords: Gamma-aminobutyric acid, Glutamate decarboxylase, Escherichia coli, Whole-cell biocatalyst, Bioconversion

\section{Background}

Gamma-aminobutyric acid (GABA) is a four-carbon non-protein amino acid that is ubiquitous in bacteria, plants and vertebrates (Diana et al. 2014). GABA has been used extensively in functional foods and pharmaceuticals, because it can act as an efficient neurotransmitter in vertebrates (Wong et al. 2003). In addition, GABA can converted into 2-pyrrolidone, an intermediate in the synthesis of nylon 4 and agrochemicals, which broaden its industrial applications (Park et al. 2013; Yamano et al. 2013). Nowadays, the majority of the GABA was chemically synthesized from 4-chlorobutyronitrile, 2-pyrrolidone or 4-butyrolactone, however, chemical synthesis often resulted in environmentally unfriendly and cost-ineffective purification (Additional file 1: Table S1). Therefore, a strategy for economical production of

\footnotetext{
*Correspondence: hjz@fjnu.edu.cn

${ }^{1}$ National Engineering Research Center of Industrial Microbiology and Fermentation Technology, College of Life Sciences, Fujian Normal University, Fuzhou 350108, Fujian, China

Full list of author information is available at the end of the article
}

biologically produced GABA for an industrial scale is eagerly demanded.

GABA is a natural metabolic intermediate in organisms, which can be synthesized via decarboxylation of glutamate by glutamate decarboxylase (GAD; EC 4.1.1.15) (Dhakal et al. 2012). There are many reports on the production of GABA by direct fermentation using natural or recombinant microorganisms (Pham et al. 2015; Shi et al. 2013). Among them, lactic acid bacteria (LAB) who contain inherent GABA synthesis pathway, produced high level of GABA in MSG-containing medium (Kook and Cho 2013; Li et al. 2010). However, an accompanying separation processes needed to be developed, and these processes were too complex to increase the cost of GABA purification (Kang et al. 2013). Recently, GABA could efficiently converted from glutamate (MSG) and L-glutamic acid (L-Glu) using purified GAD or microorganisms expressing GAD (Kang et al. 2013; Lammens et al. 2009). Together with high efficiency of MSG/L-Glu fermentation, bioconversion of MSG/LGlu into GABA was more economically than the fermentative methods (Hermann 2003). 
Glutamate decarboxylase, a pyridoxal $5^{\prime}$-phosphate (PLP)-dependent enzyme, is a key factor for the bioconversion. Due to its role in bacterial glutamate-based acid resistance system, most natural GADs exhibited their highest decarboxylase activity only under the acidic conditions (De Biase and Pennacchietti 2012; Kanjee and Houry 2013). This characteristic of $\mathrm{pH}$-response was disadvantageous to GAD used in producing GABA, because the $\mathrm{pH}$ increase as the reaction proceeded would inactivate GAD and limited the conversion (Gut et al. 2006). Since the crystal structures of $E$. coli GADs revealed the structural basis for its optimal activity at acidic $\mathrm{pH}$, several mutants with high activity toward more alkaline $\mathrm{pH}$ values have been constructed to improve GABA production (Choi et al. 2015; Shi et al. 2014; Thu Ho et al. 2013). On the other hand, hydrochloric acid, sodium acetate buffer and acidic cation-exchange resins were used to maintain the acidic condition during reaction from MSG into GABA, and the conversion efficiency were remarkably improved (Dinh et al. 2014; Park et al. 2013; Plokhov et al. 2000). However, these methods were also unsatisfactory for the following separation and purification of GABA due to the introduction of the high amount of salts or resins. In recent years, L-Glu was widely applied as substrate for keeping the acidic $\mathrm{pH}$ in non-buffered reaction with purified or immobilized GAD (Kang et al. 2013; Lammens et al. 2009; Yamano et al. 2013). Despite of the high conversion yield and the simple downstream separation, it was not suitable for industrial scale because of the tedious preparation of purified GAD and the requirement of expensive cofactor PLP.

In comparison to the purified enzymes method, wholecell bioconversion is an attractive way due to its great efficiency, relatively easy preparation and low cost, which is of particular interest for large-scale applications (Schuurmann et al. 2014). In that case, E. coli was the most common whole-cell baiocatlyst (Tam et al. 2012; Vo et al. 2013; Yamano et al. 2013). For example, Plokhov et al. used recombinant $E$. coli strain as whole-cell biocatalyst, $138 \mathrm{~g}$ GABA was achieved from $200 \mathrm{~g} \mathrm{~L}$-Glu at a conversion yield of $98.5 \%$ (Plokhov et al. 2000); Naoko et al. used E. coli NBRC 3806 as the whole-cell biocatalyst, $303.7 \mathrm{~g}$ GABA was produced from $560 \mathrm{~g}$ L-Glu via repeating 14 times (Yamano et al. 2013). Except for $E$. coli, Bacillus subtilis and Lactobacillus brevis resting cell were also used as the whole-cell biocatalyst, however, the production was not so attractive for industrial scale (Zhang et al. 2012, 2014). Moreover, the presence of the cell envelopes was able to stabilize the intracellular glutamate decarboxylase and made it less material adsorption.

In this study, we constructed a recombinant $E$. coli to produce GABA by overexpressing L. lactis gadB. Then, an efficient whole-cell biocatalytic process for GABA production from L-Glu was developed by optimizing reaction temperatures, biocatalyst and substrate concentrations. The competing pathway was removed to reduce the degradation of GABA. Finally, crude L-Glu provided by Wuyi Gourmet Powder Factory was used for converting into GABA to investigate the possibility of connecting the whole-cell biocatalytic process with the actual MSG production process.

\section{Methods}

\section{Bacterial strains and plasmids}

The plasmids and bacterial strains used in this study were listed in Table 1. E. coli BW25113 and its derivative strains were used for GADs expression and GABA production, while E. coli DH5 $\alpha$ was used for gene cloning and plasmid maintenance. Plasmid pCP20 was used to remove the kan gene, and the P1 phage was used to delete the $\operatorname{gadB}$ gene in $E$. coli $\triangle \operatorname{gadA}$ (Baba et al. 2006; Thomason et al. 2007).

\section{Construction of plasmids}

Standard methods were used for PCR, ligation, plasmid construction, extraction of plasmid DNA and genomic DNA and transformation (Green and Sambrook 2012). DNA polymerases, restriction endonucleases, T4 DNA ligase, and vector were purchased from NEB (New England BioLabs, China).

The $\operatorname{gadB}$ genes were synthesized according to the sequences from genomic DNA of three different strains, including $L$. brevis, L. lactis and L. plantarum with codon optimization (GenBank accession AIC75915; AAK05388; EFK28268). Nucleotide sequences of three codon-optimized $\operatorname{gadB}$ genes were submitted to GenBank under the accession number KT966875, KT966877 and KT966876. $\operatorname{gadB}$ genes, with the restriction sites $\mathrm{XhoI}$ upstream and SpeI downstream, were digested by XhoI and SpeI, and then ligated into the plasmids.

\section{Gene disruption}

The gadA and $\operatorname{gadB}$ double mutant was disrupted by P1 transduction (Thomason et al. 2007). Briefly, the phage P1 was grown on the donor strain $\triangle \operatorname{gadB}$ containing the transferable elements, and the resulting phage lysate was used to infect the recipient $E$. coli $\triangle g a d A$ strain. The kan gene was eliminated using the plasmid pCP20, which encodes the FLP recombinase. The mutant strain was confirmed by PCR amplification with primers (forward, 5'-TTAAACACGAGTCCTTTGC-3' and reverse, 5'AGCAGGAAGAAGACTAATGA-3 ${ }^{\prime}$ ) and sequencing.

\section{E. coli cultivation in shake flasks}

Escherichia coli strains were grown in LB medium $\left(10 \mathrm{~g} \mathrm{~L}^{-1}\right.$ tryptone, $5 \mathrm{~g} \mathrm{~L}^{-1} \mathrm{NaCl}$, and $5 \mathrm{~g} \mathrm{~L}^{-1}$ yeast 
Table 1 The strains and plasmids used in this study

\begin{tabular}{|c|c|c|}
\hline Strains or plasmids & Descriptions & References \\
\hline \multicolumn{3}{|l|}{ E. coli strains } \\
\hline $\mathrm{DH} 5 \mathrm{a}$ & 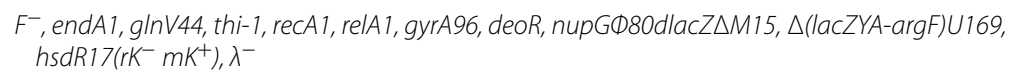 & Lab stock \\
\hline BW25113 & $F^{-}, \triangle(\operatorname{araBAD}) 567, \Delta \operatorname{acZ} 4787\left(: . r r n B_{3}\right), \lambda^{-}, r p h-1, \Delta(r h a B A D) 568$, hsdR514 & Baba et al. (2006) \\
\hline$\triangle g a d A$ & JW3485, gadA null mutant of BW25113 & Baba et al. (2006) \\
\hline$\triangle g a d B$ & JW1488, gadB null mutant of BW25113 & Baba et al. (2006) \\
\hline$\triangle g a d T$ & JW2637, gabT null mutant of BW25113 & Baba et al. (2006) \\
\hline$\triangle g a d A B$ & gadA and gadB null mutant of BW25113 & This study \\
\hline \multicolumn{3}{|l|}{ Plasmids } \\
\hline pCP20 & $\mathrm{Flp}^{+}, \lambda \mathrm{cl} 857^{+}, \lambda \mathrm{PR} \operatorname{Rep}\left(\mathrm{pSC} 101 \mathrm{ori}^{\mathrm{ts}}, \mathrm{Ap}^{r}, \mathrm{Cm}^{r}\right.$ & Datsenko and Wanner (2000) \\
\hline pYB1S & p15A ori, arabinose-inducible araBAD promoter, Strr & Lab stock \\
\hline pRB1S & RSF1020 ori, arabinose-inducible araBAD promoter, Str ${ }^{r}$ & Lab stock \\
\hline pAB1S & colA ori, arabinose-inducible araBAD promoter, Str' & Lab stock \\
\hline pDB1S & cloDF13 ori, arabinose-inducible araBAD promoter, Str ${ }^{r}$ & Lab stock \\
\hline pSB1S & pSC101 ori, arabinose-inducible araBAD promoter, Str ${ }^{r}$ & Lab stock \\
\hline pUB1S & colE1 ori, arabinose-inducible araBAD promoter, Str ${ }^{r}$ & Lab stock \\
\hline pYB-bgadB & pRB1S with gadB from L. brevis $\mathrm{BH} 2$ & This study \\
\hline pYB-pgadB & pRB1S with gadB from L. plantarum ATCC 14917 & This study \\
\hline pYB-lgadB & pRB1S with gadB from L. lactis IL1403 & This study \\
\hline pAB-lgadB & pAB1S with gadB from L. lactis IL1403 & This study \\
\hline pDB-IgadB & pDB1S with gadB from L. lactis IL1403 & This study \\
\hline pSB-lgadB & pSB1S with gadB from L. lactis IL 1403 & This study \\
\hline pUB-lgadB & pUB1S with gadB from L. lactis IL1403 & This study \\
\hline pRB-lgadB & pYB1S with gadB from L. lactis IL 1403 & This study \\
\hline
\end{tabular}

extract) containing $50 \mathrm{mg} \mathrm{L}^{-1}$ streptomycin at $30^{\circ} \mathrm{C}$ with shaking at $200 \mathrm{rpm}$. Then, $1 \%$ pre-culture was transferred into $50 \mathrm{~mL}$ of ZYM medium (Studier 2005) with $50 \mathrm{mg} \mathrm{L}^{-1}$ streptomycin in $250 \mathrm{~mL}$ shake flask for GADs expression. Cells were cultivated at $30{ }^{\circ} \mathrm{C}$ for $16 \mathrm{~h}$ with shaking at $200 \mathrm{rpm}$.

\section{Fed-batch cultivation}

For seed cultures, the E. coli was inoculated into $350 \mathrm{~mL}$ of LB medium containing $50 \mathrm{mg} \mathrm{L}^{-1}$ streptomycin in a $1 \mathrm{~L}$ flask at $30{ }^{\circ} \mathrm{C}$ for $8 \mathrm{~h}$ with shaking at $200 \mathrm{rpm}$. Then, seed cultures was transferred into $35 \mathrm{~L}$ of fresh basal medium $\left(5 \mathrm{~g} \mathrm{~L}^{-1}\right.$ yeast extract, $9 \mathrm{~g} \mathrm{~L}^{-1} \mathrm{KH}_{2} \mathrm{PO}_{4}, 4 \mathrm{~g} \mathrm{~L}^{-1}$ $\left(\mathrm{NH}_{4}\right)_{2} \mathrm{HPO}_{4}$ and $\left.0.6 \mathrm{~g} \mathrm{~L}^{-1} \mathrm{MgSO}_{4}\right)$ containing $20 \mathrm{~g} \mathrm{~L}^{-1}$ glucose and $50 \mathrm{mg} \mathrm{L}^{-1}$ streptomycin in a $50 \mathrm{~L}$ jar bioreactor. In the fed-batch cultivation, glucose concentration was maintained at $0.5 \mathrm{~g} \mathrm{~L}^{-1}$ in the broth to avoiding the glucose limitation. During the cultivation, temperature was maintained at $30{ }^{\circ} \mathrm{C} ; \mathrm{pH}$ was maintained at $\mathrm{pH} 6.7$ by adding ammonia water; dissolved oxygen was maintained at $20 \%(\mathrm{v} / \mathrm{v})$ by automatically increasing the agitation speed up to $600 \mathrm{rpm}$ with $1.0 \mathrm{vvm}$ air flow rate.

\section{Bioconversion conditions}

After induction, the cells were collected by centrifugation at $8000 \times g$ for $10 \mathrm{~min}$ and then resuspended in $0.1 \mathrm{M}$ sodium acetate buffer ( $\mathrm{pH}$ 4.6) with MSG or deionized water (DW) with L-Glu at appropriate concentration. The reaction mixtures were adjusted to different temperatures, cell densities and substrate concentrations to improve the GABA production. After the process was optimized, the cells were incubated at $45{ }^{\circ} \mathrm{C}$ with the addition of $3 \mathrm{M}$ Glu to investigate the production of GABA. The same batch of cells were used three runs in $2 \mathrm{M}$ crude $\mathrm{L}$-Glu solution for each time to produce GABA. For each round of the cycling reaction, cells were harvested and adjusted to $\mathrm{OD}_{600}$ of 15 , then mixed with L-Glu directly.

\section{Analytical methods}

The cell density was estimated by measuring the optical density at $600 \mathrm{~nm}\left(\mathrm{OD}_{600}\right)$. One unit of $\mathrm{OD}_{600}$ corresponds to a wet cell weight of $0.83 \pm 0.01 \mathrm{~g} \mathrm{~L}^{-1}$. Expression of recombinant GADs was analyzed by $12 \%$ sodium dodecyl sulfate polyacrylamide gel electrophoresis (SDS-PAGE). 
The concentrations of GABA and L-Glu were measured by HPLC with the phenylisothiocyanate derivation method, equipped with Hypersil GOLD C18 analysis column $(250 \mathrm{~mm} \times 4.6 \mathrm{~mm}, 5 \mu \mathrm{m}$, Thermo). The derivatization reagent consisting of phenylisothiocyanate/triethylamine/acetonitrile (0.02:0.18:2.3) solution $(2.5 \mathrm{~mL})$ was added to $2.5 \mathrm{~mL}$ of the supernatant. The mixture was incubated at $40{ }^{\circ} \mathrm{C}$ for $60 \mathrm{~min}$. Then, $5 \mathrm{~mL}$ hexane was added to stop the reaction, shaken and aside for $10 \mathrm{~min}$. The reacted solutions was analyzed at $40^{\circ} \mathrm{C}$ using a linear gradient of two mobile phases (eluent A: acetonitrile; eluent B: $50 \mathrm{mM}$ sodium acetate, linear gradient of $0-70 \%$ eluent $B$ in $15 \mathrm{~min}$ ) at a flow rate of $0.8 \mathrm{~mL} \mathrm{~min}^{-1}$ and monitored at $254 \mathrm{~nm}$ (Takeda et al. 2012). The standard curves for GABA and L-Glu (Sigma, Missouri, USA) were determined using the same procedure.

\section{Results and discussion}

\section{Construction of recombinant $E$. coli for the production of GABA}

Initially, MSG was used as the substrate for wholecell bioconversion of wild-type $E$. coli. However, only $7.86 \mathrm{~g} \mathrm{~L}^{-1} \mathrm{GABA}$ was produced within $6 \mathrm{~h}$, indicating the wild-type $E$. coli was not suitable as whole-cell biocatalysts for conversion into GABA. Thus, we constructed recombinant $E$. coli strains by overexpressing codonoptimized L. lactis GadB, L. plantarum GadB and $L$. brevis GadB from middle copy-number plasmid (pYB1S) under the regulation of $\mathrm{P}_{\text {araBAD }}$ promoter. The SDS-PAGE result showed the three $\operatorname{gadB}$ genes were successfully expressed, and the GadB proteins were produced with high solubility (Additional file 1: Fig. S1).

The effect of three candidate strains with different GadB genes on production of GABA was examined. We resuspended the strains with an $\mathrm{OD}_{600}$ of 30 in $0.1 \mathrm{M}$ sodium acetate buffer ( $\mathrm{pH}$ 4.6) containing 1 M MSG for bioconversion at $37{ }^{\circ} \mathrm{C}$. As a result, recombinant E. coli BW25113 expresses L. lactis GadB was the most active whole-cell biocatalyst for GABA production, which resulted in the synthesis of $45.58 \mathrm{~g} \mathrm{~L}^{-1}$ GABA with a $44.2 \mathrm{~mol} \%$ conversion within $6 \mathrm{~h}$ (Fig. 1a). The other two recombinant $E$. coli harboring $L$. brevis GadB and $L$. plantarum GadB produced lower GABA concentration of 31.12 and $18.97 \mathrm{~g} \mathrm{~L}^{-1}$, respectively.

\section{Glutamic acid is a good buffer for bioconversion}

High concentration of MSG and GABA that contained ionizable alpha-amino groups made the bioconversion reaction maintain at near-neutral $\mathrm{pH}$ environment, which was beyond the active range of wild-type GAD. Instead of using buffer solution with the MSG in the reaction, we applied pure L-Glu to achieve acidic $\mathrm{pH}$
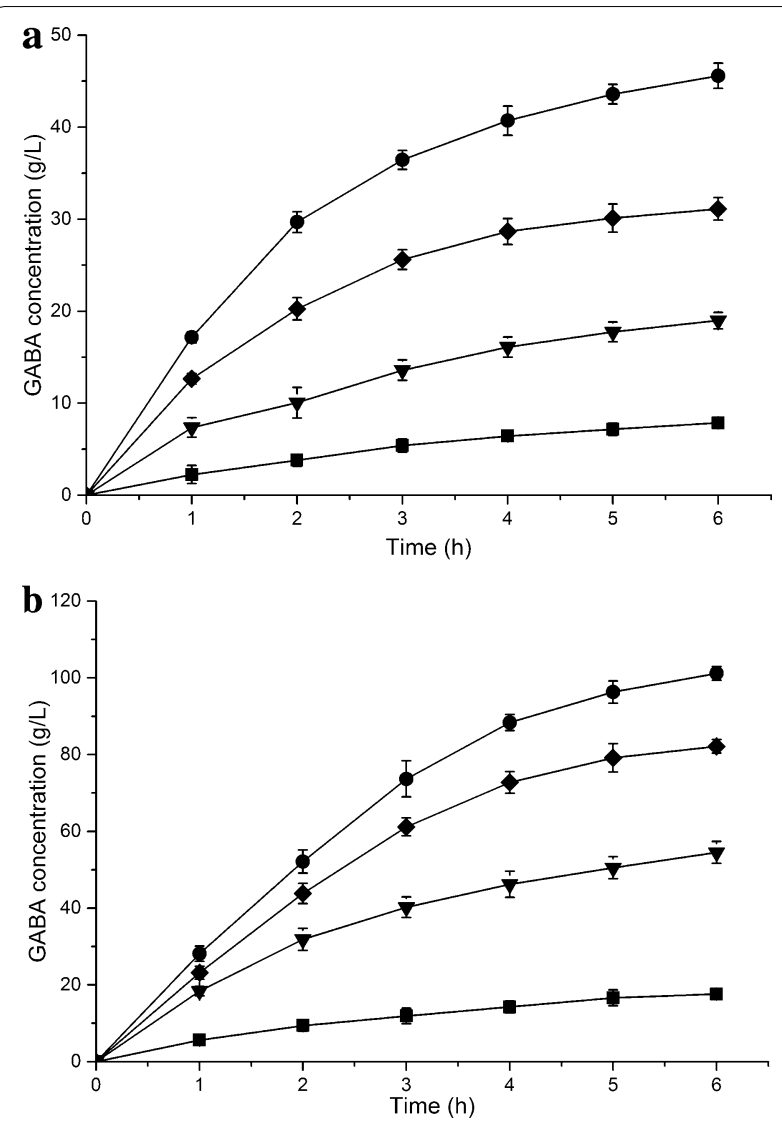

Fig. 1 Time profiles of GABA produced in a MSG buffer and $\mathbf{b} \mathrm{L}-\mathrm{Glu}$ solution by E. coli BW25113 expressing different GadB. Conversions were performed at $37^{\circ} \mathrm{C}$ and $25 \mathrm{~g}$ wet cell per liter. Data are presented as the mean $\pm S D$ values from three independent experiments. Square, down triangle, diamond and circle symbolize the E. coli BW25113 and recombinant E. coli BW25113 harboring pYB-pgadB, pYB-bgadB and pYB-IgadB, respectively

at the start of the bioconversion. Three recombinant $E$. coli strains produced GABA in water with adding $1 \mathrm{M}$ L-Glu at one time. At the beginning, L-Glu was partially dissolved in water, then dissolved better as the conversion proceeded. Finally, L-Glu was dissolved completely in the system, which meant almost all of the L-Glu was converted into GABA. As we expected, the three strains with L-Glu as the substrate showed higher efficiency and higher molar yield of GABA production than using MSG (Fig. 1b). The highest production of GABA was achieved at $101.16 \mathrm{~g} \mathrm{~L}^{-1}(0.98 \mathrm{M})$ using recombinant $E$. coli expressing L. lactis GadB, with a $220 \%$ improvement compared to that obtained in 1 M MSG buffer (pH 4.6) within $6 \mathrm{~h}$. Based on these results, recombinant $E$. coli expressing L. lactis GadB was selected for further investigations on the production of GABA using L-Glu as the substrate. 


\section{Synthesis of GABA by recombinant $E$. coli harboring different plasmids}

To provide appropriate expression level of L. lactis gadB in E. coli for GABA production, six different plasmids from a relatively low copy-number $(\sim 5)$ to high copy-number ( 300) were applied. Recombinant E. coli BW25113 strains harboring pSB-lgadB, pAB-lgadB, pYB$\operatorname{lgadB}, \mathrm{pRB}-\operatorname{lgadB}, \mathrm{pDB}$-lgadB and pUB-lgadB were investigated for the conversion of L-Glu into GABA (Fig. 2). To our surprise, the strain with the highest copy-number plasmid (E. coli BW25113 harboring pUB-lgadB) was only produced $80.33 \mathrm{~g} \mathrm{~L}^{-1} \mathrm{GABA}$ within $6 \mathrm{~h}$. The highest GABA production $\left(102.19 \mathrm{~g} \mathrm{~L}^{-1}\right)$ was achieved by recombinant $E$. coli harboring middle copy-number plasmid (pRB-lgadB) within $5 \mathrm{~h}$ with a space-time productivity of $20.44 \mathrm{~g} \mathrm{~L}^{-1} \mathrm{~h}^{-1}$. The result indicated a moderate rather strong expression of GAD was efficient for GABA production, and the soluble expression levels of GAD were not correlated with the production and the productivity of GABA (Additional file 1: Fig. S2). Moreover, the low copy-number indeed had the negative effect on GABA production, for example, recombinant E. coli harboring pSB-lgadB (the lowest copy-number) produced only $42.21 \mathrm{~g} \mathrm{~L}^{-1} \mathrm{GABA}$ within $6 \mathrm{~h}$.

\section{Optimization of bioconversion system for GABA synthesis}

As previously reported, the temperature of the reaction was a core factor for glutamate decarboxylase activity (Lammens et al. 2009; Plokhov et al. 2000; Zhang et al. 2014). Thus, the conversion efficiency of E. coli BW25113 harboring pRB-lgadB was examined at five different temperature conditions $(33,37,41,45$ and $50{ }^{\circ} \mathrm{C}$ ) (Fig. 3a). The highest volumetric productivity of GABA (34.04 $\mathrm{g} \mathrm{L}^{-1} \mathrm{~h}^{-1}$ ) was obtained at $45{ }^{\circ} \mathrm{C}$, which

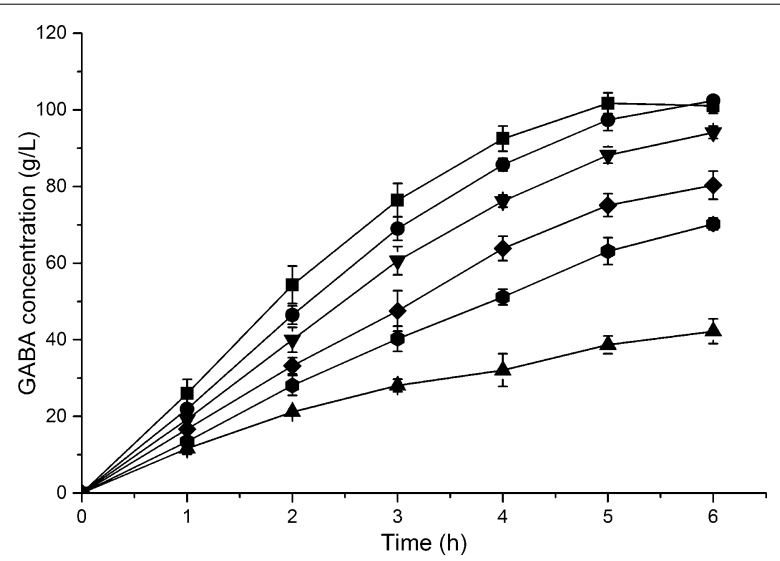

Fig. 2 Production of GABA by recombinant E. coli harboring different plasmids. Square, circle, down triangle, diamond, hexagon and up triangle symbolize the recombinant $E$. coli harboring pRB-lgadB, pYBIgadB, pDB-lgadB, pUB-IgadB, pAB-lgadB and pSB-lgadB, respectively was 1.67 times higher than previous study at $37{ }^{\circ} \mathrm{C}$ (20.44 $\left.\mathrm{g} \mathrm{L}^{-1} \mathrm{~h}^{-1}\right)$. Consequently, $102.13 \mathrm{~g} \mathrm{~L}^{-1} \mathrm{GABA}$ with a molar yield of $99.1 \%$ was produced within $3 \mathrm{~h}$ at $45^{\circ} \mathrm{C}$, and this result consisted with the optimum temperature of purified GAD (EC 4.1.1.15) in L. lactis (Nomura et al. 1999).

To improve the total production of GABA during whole-cell bioconversion, the cell productivity was also investigated (Fig. 3b). Comparing with the strain concentrated to $\mathrm{OD}_{600}$ of 30 in previous study, the cell productivity of GABA was significantly improved as the cell amount decreasing. The cell productivity increased to a peak $\left(9.28 \mathrm{~g} / \mathrm{g}\right.$ wet cell) using the strain with $\mathrm{OD}_{600}$ of 5 , however, the GABA production only reached $38.53 \mathrm{~g} \mathrm{~L}^{-1}$ with $37.4 \mathrm{~mol} \%$ conversion. Despite of a little lower cell productivity $(8.13 \mathrm{~g} / \mathrm{g}$ wet cell), the GABA production was achieved at $101.26 \mathrm{~g} \mathrm{~L}^{-1}$ with $98.2 \mathrm{~mol} \%$ conversion using the strain with $\mathrm{OD}_{600}$ of 15 . Furthermore,GABA yield only increased a little (1.71-2.33 $\left.\mathrm{g} \mathrm{L}^{-1}\right)$ when the strain concentrated to $\mathrm{OD}_{600}$ over 15 , while the cell productivity fell a lot $(6.2-4.1 \mathrm{~g} / \mathrm{g}$ wet cell). Therefore, the strain with an $\mathrm{OD}_{600}$ of 15 was more applicable for the whole cell bioconversion.

\section{Effect of substrate concentration on GABA production}

A series of L-Glu concentrations was used for wholecell bioconversion to determine the influence of initial L-Glu concentration on GABA production. Time profiles of GABA production showed that the GABA yield increased with higher initial L-Glu concentration at the cost of conversion time (Fig. 4a). The most efficient system was controlling the initial concentrations of L-Glu less than $2.5 \mathrm{M}$, in that case, almost all of L-Glu was consumed within $6 \mathrm{~h}$ with producing an equal molar amount of GABA (Fig. 4b). Interestingly, the presence of GABA could promote the solubility of L-Glu, therefore, the concentration of L-Glu increased in the early stages (Additional file 1: Fig. S3). When the initial L-Glu concentration increased to $3 \mathrm{M}$, the conversion time prolonged to $12 \mathrm{~h}$ for consuming almost all the $\mathrm{L}-\mathrm{Glu}$, and the production reached $303.75 \mathrm{~g} \mathrm{~L}^{-1}$ with $98.2 \mathrm{~mol} \%$ conversion (Fig. 5). Further increase in the initial concentration, L-Glu could not be completely converted to GABA even though longer conversion times (up to $24 \mathrm{~h}$ ) was spent (data not shown). As a result, the highest volumetric productivity of GABA $\left(41.12 \mathrm{~g} \mathrm{~L}^{-1} \mathrm{~h}^{-1}\right)$ was achieved using $2 \mathrm{M} \mathrm{L-Glu}$ as the substrate, which resulted in the production of $205.61 \mathrm{~g} \mathrm{~L}^{-1}$ GABA with a conversion of $99.7 \mathrm{~mol} \%$. For the record, this is the highest volumetric productivity level of GABA produced by whole-cell bioconversion from L-Glu, even compared with conversion using the purified or immobilized GAD $\left(35 \mathrm{~g} \mathrm{~L}^{-1} \mathrm{~h}^{-1}\right)$ (Kang et al. 2013; Lammens et al. 2009). 

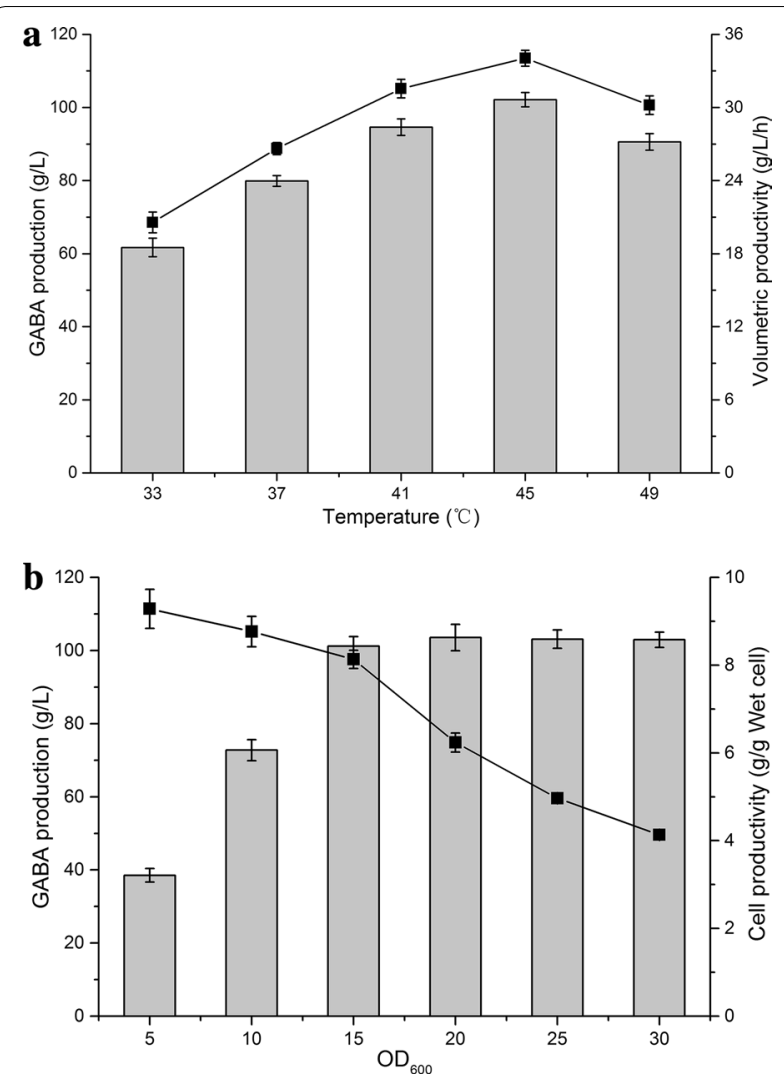

Fig. 3 Effects of reaction condition on GABA production. Conversion reactions were performed at different $\mathbf{a}$ temperature and $\mathbf{b}$ cell concentrations with shaking at $200 \mathrm{rpm}$ for $3 \mathrm{~h}$. Data are presented as the mean $\pm S D$ values from three independent experiments. The bars represent GABA concentrations and the square symbols represent $\mathbf{a}$ volumetric productivity, $\mathbf{b}$ cell productivity

\section{Effect of blocking competitive pathways in GABA production}

It is worth noting that the GABA concentration strikingly degraded from $303.75 \mathrm{~g} \mathrm{~L}^{-1}$ obtained from $3 \mathrm{M}$ Glu within $12 \mathrm{~h}$ to $289.07 \mathrm{~g} \mathrm{~L}^{-1}$ during $30 \mathrm{~h}$ (Fig. 5). GABA aminotransferase (GabT), which directed GABA to the TCA cycle, was considered to be the main cause of GABA degradation (Tam et al. 2012). Therefore, E. coli $\triangle g a b T$ harboring pRB-lgadB was constructed as wholecell biocatalyst to investigate GABA production. Recombinant E. coli $\triangle g a b T$ indeed impeded the degradation of GABA, but it produced $273.96 \mathrm{~g} \mathrm{~L}^{-1}$ GABA by consuming $89 \%$ of $3 \mathrm{M} \mathrm{L}-$ Glu within $42 \mathrm{~h}$, which was only $25.9 \%$ of the volumetric productivity obtained from the best strain $\left(25.44 \mathrm{~g} \mathrm{~L}^{-1} \mathrm{~h}^{-1}\right)$. The result was similar with previously reported, because $E$. coli $\Delta g a b T$ caused a metabolic burdens, which lead to lower cellular metabolic activity (Tam et al. 2012).

Interestingly, when the chromosomal $\operatorname{gad} A, \operatorname{gadB}$ or both were knocked out, the degradation of GABA was
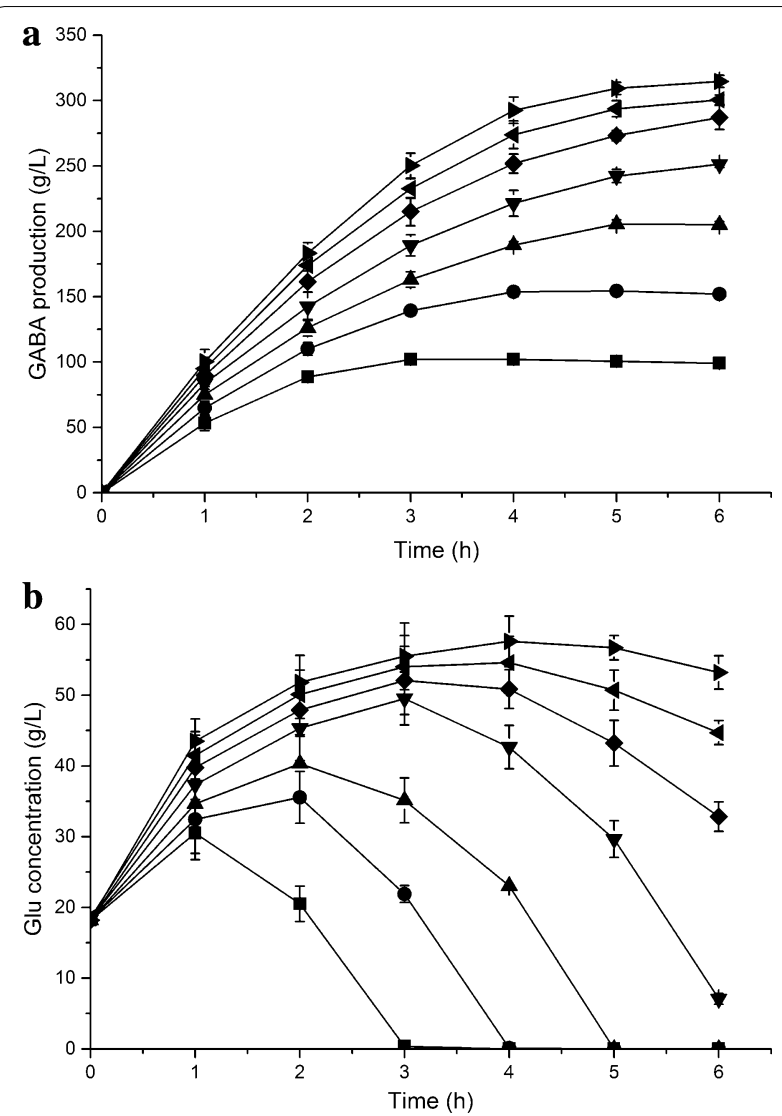

Fig. 4 Time profiles of $\mathbf{a}$ GABA and $\mathbf{b}$ residual L-Glu concentration during conversion in different $\mathrm{L}-\mathrm{Glu}$ concentrations. Conversions were performed at $45^{\circ} \mathrm{C}$ and $12.5 \mathrm{~g}$ wet cell per liter $\left(\mathrm{OD}_{600}\right.$ of 15$)$. Data are presented as the mean \pm SD values from three independent experiments. Square, circle, up triangle, down triangle, diamond, left triangle and right triangle represent the concentrations of L-Glu: 1, 1.5, 2, 2.5, 3, 3.5 and $4 \mathrm{M}$, respectively

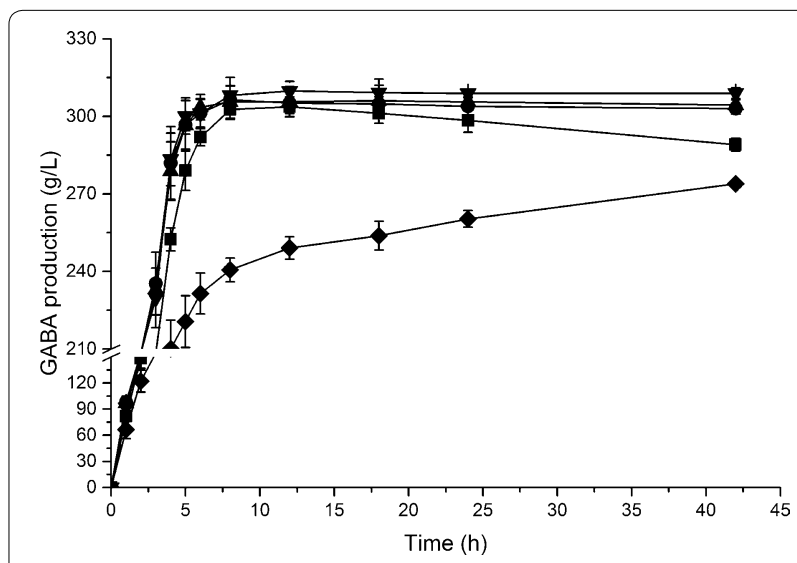

Fig. 5 Time profiles of GABA concentration were obtained using various strains. Diamond, square, up triangle, circle and down triangle represent the recombinant E. coli $\triangle$ gabT, E. coli BW25113, E. coli $\triangle$ gadB, E. coli $\triangle$ gadA and E. coli $\triangle$ gadAB harboring pRB-lgadB, respectively 


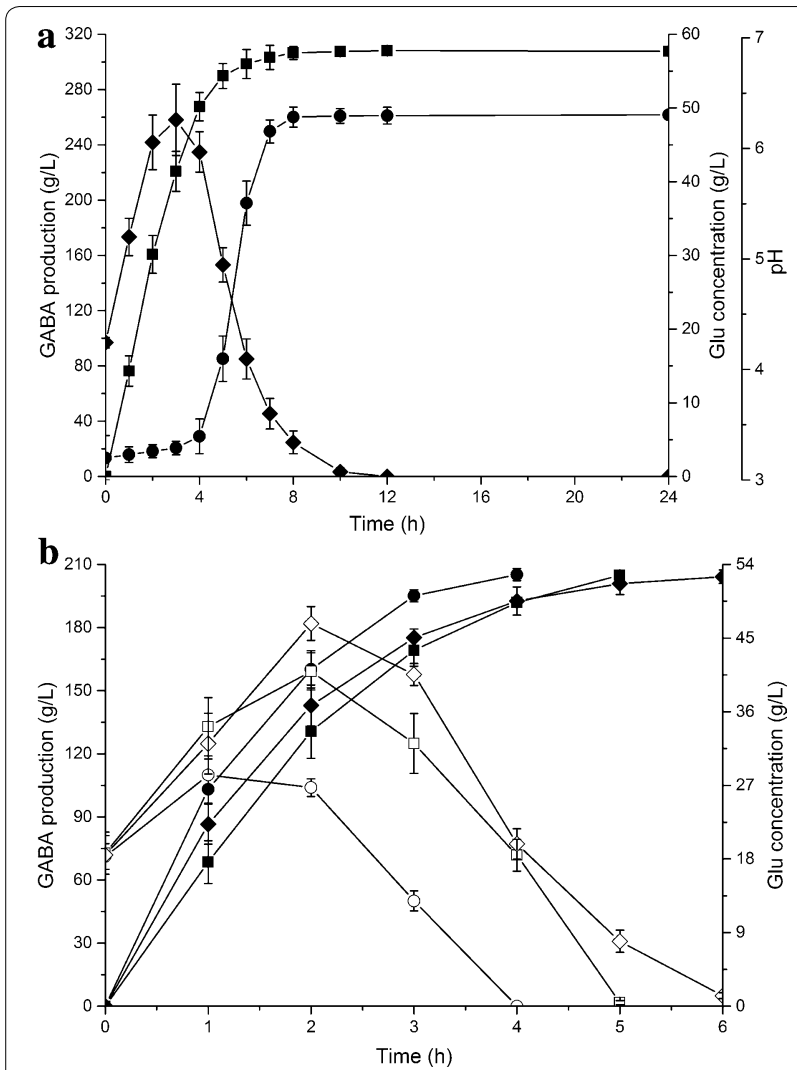

Fig. 6 Time profiles of GABA synthesis from a $3 \mathrm{M}$ and $\mathbf{b} 2 \mathrm{M}$ crude L-Glu solution. a Time course where diamond, square and circle represent L-Glu concentration, GABA production and $\mathrm{pH}$, respectively. b Repeated use of cells where square, circle and diamond represent cycle 1, cycle 2 and cycle 3, respectively; filled shapes GABA concentrations; open shapes residual L-Glu concentrations

also prevented without influence the conversion yield. After $42 \mathrm{~h}$, over $303 \mathrm{~g} \mathrm{~L}^{-1}$ GABA remained in the reaction solution with less than $1 \%$ degradation when using the mutant $E$. coli $\triangle \operatorname{gadA}$ or $E$. coli $\triangle \operatorname{gadB}$ as host strain. Meanwhile, E. coli $\triangle$ gadAB harboring pRB-lgadB achieved the highest GABA concentration of $308.96 \mathrm{~g}$ $\mathrm{L}^{-1}$, and had only $0.25 \%$ degradation of GABA for lasting $30 \mathrm{~h}$. Based on these results, knocking out the chromosomal $\operatorname{gad} A$ and $\operatorname{gadB}$ gene in $E$. coli might be an efficient metabolic engineering strategy to prevent the degradation of GABA.

\section{Whole-cell biocatalysis of GABA from crude Glu}

Fed-batch cultivations was carried out to obtain a higher cell concentration $\left(\mathrm{OD}_{600}\right.$ of 60$)$ of E. coli $\triangle g a b A B$ harboring $\mathrm{pRB}$-lgadB. The bioconversion was performed in $200 \mathrm{~L}$ reactor by $15 \mathrm{OD}$ cells suspended in $160 \mathrm{~L}$ deionized water with initial addition of $88.5 \mathrm{~kg}$ crude L-Glu at one time. Crude L-Glu, prepared from actual glutamate production process, was provided by Wuyi Gourmet Powder Factory. The $\mathrm{pH}$ of reaction mixture increased from 3.21 to 6.31 during $12 \mathrm{~h}$ conversion, and almost all of crude L-Glu were converted into GABA with a yield of $308.13 \mathrm{~g} \mathrm{~L}^{-1}$. Although the undetermined impurities were existed in crude L-Glu compared to chemical pure L-Glu, the conversion progressed smoothly with high GABA production and productivity (volumetric productivity: $25.68 \mathrm{~g} \mathrm{~L}^{-1} \mathrm{~h}^{-1}$, cell productivity: $24.75 \mathrm{~g} / \mathrm{g}$ wet cell) (Fig. 6a). Notably, although our cell productivity was at the same level with the highest report $(23-25 \mathrm{~g} / \mathrm{g}$ wet cell), the volumetric productivity of our system was twice higher than that report $\left(8-8.6 \mathrm{~g} \mathrm{~L}^{-1} \mathrm{~h}^{-1}\right.$ ) (Plokhov et al. 2000). Moreover, that report used thermally activated cells (incubation at $53{ }^{\circ} \mathrm{C}$ for $1 \mathrm{~h}$ ) and $0.04 \mathrm{mM}$ PLP in the cluture medium, while we did not need any pretreatment and addition of expensive cofactor.

The reusability of biocatalyst is a key factor for the efficiency of the whole-cell bioconversion in industrial application. Due to the highest volumetric productivity from $2 \mathrm{M} \mathrm{L}$-Glu as the substrate, cycling of the recombinant E. coli cells was investigated using $2 \mathrm{M}$ crude L-Glu as the initial concentration (Fig. 6b). In cycle 1, all L-Glu was converted to GABA in $5 \mathrm{~h}$ with a yield of $204.87 \mathrm{~g} \mathrm{~L}^{-1}$. In cycle 2 , the complete conversion only lasted $4 \mathrm{~h}$ with a yield of $205.13 \mathrm{~g} \mathrm{~L}^{-1}$. However, in cycle 3 , the conversion time was increased to $6 \mathrm{~h}$ to achieve over 99 mol\% conversion. Notably, cells disruption were observed during the bioconversion, and about $10 \%$ or more cell loss after completion of each round (Additional file 1: Fig. S4). Thus, one batch of cells could be reused for at least three cycles at a conversion yield over 99 mol\% using $2 \mathrm{M}$ crude $\mathrm{L}-\mathrm{Glu}$, and the total GABA production reached $614.15 \mathrm{~g} \mathrm{~L}^{-1}$ within $15 \mathrm{~h}$. The high production and productivity of our bioconversion is a promising cost-effective resource for GABA in industrial application.

\section{Conclusions}

In this study, a process of GABA production from L-Glu using E. coli $\triangle g a b A B$ overexpression of L. lactis GadB as whole-cell biocatalyst was developed. Without the addition of co-factor PLP, the highest GABA concentration was achieved at $308.96 \mathrm{~g} \mathrm{~L}^{-1}$ within $12 \mathrm{~h}$, when engineered $E$. coli concentrated to an $\mathrm{OD}_{600}$ of 15 in $3 \mathrm{M}$ L-Glu at $45{ }^{\circ} \mathrm{C}$. Moreover, the engineered strain could be reused a three cycle successive conversion in $2 \mathrm{M}$ crude Glu solution, and the total GABA yield reached $614.15 \mathrm{~g} \mathrm{~L}^{-1}$. This whole-cell biocatalytic system is a costeffective process for industrial GABA production. 


\section{Additional file}

Additional file 1: Table S1. Major chemical synthesis methods of GABA. Table S2. Plasmid copy number. Fig. S1. SDS-PAGE analysis of the soluble fraction cell extracts. Fig. S2. SDS-PAGE analysis of the supernatant from cell extracts. Fig. S3. $L$-Glu solubility in different concentrations of GABA solution. Fig. S4. Protein concentrations during each cycles of GABA production.

\section{Authors' contributions}

KCR and YXW designed the research. KCR and RHX gathered data of the whole-cell bioconversion. YXW and ZWC constructed engineered Escherichia coli. HMR designed the codon optimized gadB gene. KCR drafted the manuscript, which was proofread by HJZ and TY. All authors read and approved the final manuscript.

\section{Author details}

${ }^{1}$ National Engineering Research Center of Industrial Microbiology and Fermentation Technology, College of Life Sciences, Fujian Normal University, Fuzhou 350108, Fujian, China. ${ }^{2}$ CAS Key Laboratory of Microbial Physiological and Metabolic Engineering, Institute of Microbiology, Chinese Academy of Sciences, No. 1 West Beichen Road, Chaoyang District, Beijing 100101, China.

\section{Acknowledgements}

This work received financial support from the National High Technology Research and Development Program of China (2015AA021005), the Natural Science Foundation of Fujian Province (2014J01037).

\section{Competing interests}

The authors declare that they have no competing interests.

Received: 5 February 2016 Accepted: 22 April 2016

Published online: 11 May 2016

\section{References}

Baba T, Ara T, Hasegawa M, Takai Y, Okumura Y, Baba M, Datsenko KA, Tomita M, Wanner BL, Mori H (2006) Construction of Escherichia coli K-12 inframe, single-gene knockout mutants: the Keio collection. Mol Syst Biol 2(1):1-11

Choi JW, Yim SS, Lee SH, Kang TJ, Park SJ, Jeong KJ (2015) Enhanced production of gamma-aminobutyrate (GABA) in recombinant Corynebacterium glutamicum by expressing glutamate decarboxylase active in expanded $\mathrm{pH}$ range. Microb Cell Fact 14:21

Datsenko KA, Wanner BL (2000) One-step inactivation of chromosomal genes in Escherichia coli K-12 using PCR products. Proc Natl Acad Sci USA 97(12):6640-6645

De Biase D, Pennacchietti E (2012) Glutamate decarboxylase-dependent acid resistance in orally acquired bacteria: function, distribution and biomedical implications of the gadBC operon. Mol Microbiol 86(4):770-786

Dhakal R, Bajpai VK, Baek KH (2012) Production of gaba (gamma-aminobutyric acid) by microorganisms: a review. Braz J Microbiol 43(4):1230-1241

Diana M, Quilez J, Rafecas M (2014) Gamma-aminobutyric acid as a bioactive compound in foods: a review. J Funct Foods 10:407-420

Dinh TH, Ho NAT, Kang TJ, McDonald KA, Won K (2014) Salt-free production of gamma-aminobutyric acid from glutamate using glutamate decarboxylase separated from Escherichia coli. J Chem Technol Biotechnol 89(9):1432-1436

Green MR, Sambrook J (2012) Molecular cloning: a laboratory manual. Cold Spring Harbor Laboratory Press, Cold Spring Harbor

Gut H, Pennacchietti E, John RA, Bossa F, Capitani G, De Biase D, Grutter MG (2006) Escherichia coli acid resistance: $\mathrm{pH}$-sensing, activation by chloride and autoinhibition in GadB. EMBO J 25(11):2643-2651

Hermann T (2003) Industrial production of amino acids by coryneform bacteria. J Biotechnol 104(1-3):155-172
Kang TJ, Ho NA, Pack SP (2013) Buffer-free production of gamma-aminobutyric acid using an engineered glutamate decarboxylase from Escherichia coli. Enzyme Microb Technol 53(3):200-205

Kanjee U, Houry WA (2013) Mechanisms of acid resistance in Escherichia coli. Annu Rev Microbiol 67:65-81

Kook MC, Cho SC (2013) Production of GABA (gamma amino butyric acid) by lactic acid bacteria. Korean J Food Sci An 33(3):377-389

Lammens TM, De Biase D, Franssen MCR, Scott EL, Sanders JPM (2009) The application of glutamic acid alpha-decarboxylase for the valorization of glutamic acid. Green Chem 11(10):1562-1567

Li H, Qiu T, Huang G, Cao Y (2010) Production of gamma-aminobutyric acid by Lactobacillus brevis NCL912 using fed-batch fermentation. Microb Cell Fact 9:85

Nomura M, Nakajima I, Fujita Y, Kobayashi M, Kimoto H, Suzuki I, Aso H (1999) Lactococcus lactis contains only one glutamate decarboxylase gene. Microbiology 145(Pt 6):1375-1380

Park SJ, Kim EY, Noh W, Oh YH, Kim HY, Song BK, Cho KM, Hong SH, Lee SH, Jegal J (2013) Synthesis of nylon 4 from gamma-aminobutyrate (GABA) produced by recombinant Escherichia coli. Bioproc Biosyst Eng 36(7):885-892

Pham VD, Lee SH, Park SJ, Hong SH (2015) Production of gamma-aminobutyric acid from glucose by introduction of synthetic scaffolds between isocitrate dehydrogenase, glutamate synthase and glutamate decarboxylase in recombinant Escherichia coli. J Biotechnol 207:52-57

Plokhov AY, Gusyatiner M, Yampolskaya T, Kaluzhsky V, Sukhareva B, Schulga A (2000) Preparation of $\gamma$-aminobutyric acid using $E$. coli cells with high activity of glutamate decarboxylase. Appl Biochem Biotechnnol 88(1-3):257-265

Schuurmann J, Quehl P, Festel G, Jose J (2014) Bacterial whole-cell biocatalysts by surface display of enzymes: toward industrial application. Appl Microbiol Biotechnol 98(19):8031-8046

Shi F, Jiang J, Li Y, Li Y, Xie Y (2013) Enhancement of gamma-aminobutyric acid production in recombinant Corynebacterium glutamicum by co-expressing two glutamate decarboxylase genes from Lactobacillus brevis. J Ind Microbiol Biotechnol 40(11):1285-1296

Shi F, Xie Y, Jiang J, Wang N, Li Y, Wang X (2014) Directed evolution and mutagenesis of glutamate decarboxylase from Lactobacillus brevis Lb85 to broaden the range of its activity toward a near-neutral $\mathrm{pH}$. Enzyme Microb Technol 61-62:35-43

Studier FW (2005) Protein production by auto-induction in high density shaking cultures. Protein Expr Purif 41(1):207-234

Takeda S, Yamano N, Kawasaki N, Ando H, Nakayama A (2012) Rapid determination of 4-aminobutyric acid and L-glutamic acid in biological decarboxylation process by capillary electrophoresis-mass spectrometry. J Sep Sci 35(2):286-291

Tam DLV, Kim TW, Hong SH (2012) Effects of glutamate decarboxylase and gamma-aminobutyric acid (GABA) transporter on the bioconversion of GABA in engineered Escherichia coli. Bioprocess Biosyst Eng 35(4):645-650

Thomason LC, Costantino N, Court DL (2007) E. coli genome manipulation by P1 transduction. Curr Protoc Mol Biol 1:1-17

Thu Ho NA, Hou CY, Kim WH, Kang TJ (2013) Expanding the active pH range of Escherichia coli glutamate decarboxylase by breaking the cooperativeness. J Biosci Bioeng 115(2):154-158

Vo TDL, Ko JS, Park SJ, Lee SH, Hong SH (2013) Efficient gamma-aminobutyric acid bioconversion by employing synthetic complex between glutamate decarboxylase and glutamate/GABA antiporter in engineered Escherichia coli. J Ind Microbiol Biotechnol 40(8):927-933

Wong CG, Bottiglieri T, Snead OC 3rd (2003) GABA, gamma-hydroxybutyric acid, and neurological disease. Ann Neurol 54(Suppl 6):S3-S12

Yamano N, Kawasaki N, Takeda S, Nakayama A (2013) Production of 2-pyrrolidone from biobased glutamate by using Escherichia coli. J Polym Environ 21(2):528-533

Zhang Y, Song L, Gao Q, Yu SM, Li L, Gao NF (2012) The two-step biotransformation of monosodium glutamate to GABA by Lactobacillus brevis growing and resting cells. Appl Microbiol Biot 94(6):1619-1627

Zhang C, Lu J, Chen L, Lu FX, Lu ZX (2014) Biosynthesis of gamma-aminobutyric acid by a recombinant Bacillus subtilis strain expressing the glutamate decarboxylase gene derived from Streptococcus salivarius ssp thermophilus Y2. Process Biochem 49(11):1851-1857 